\title{
COVID reflections of an emergency physician
}

\author{
Huma Ali ${ }^{1,2}$
}

Received: 14 September 2020 / Accepted: 15 October 2020 / Published online: 4 January 2021

(c) Canadian Association of Emergency Physicians (CAEP)/ Association Canadienne de Médecine d'Urgence (ACMU) 2020

The titles of each of these poems follow the poem.

The Emergency Department is empty, as if everyone died already.

Is this what the future of Emergency Medicine will look like? Quiet and dead?

$$
\text { -April } 2020
$$

I intubated you. But before I did, I held your face in my hands and said

"you're going to be okay."

You had COVID. You died, father of four.

I'm sorry I lied, I didn't know any better at the time.

-Death of an immigrant

You died and we are trying to resuscitate you.

You are lying in front of me, naked. CPR in progress.

A room full of strangers rhythmically pump your chest.

Your family is not allowed to be with you as your soul

leaves your body.

This is the loneliest way to die.

\section{-COVID deaths}

You hold my gloved hand and cry.

You cry and thank me for listening and tell me I am a hero for working the frontlines during this pandemic.

You thank me for protecting the people.
I cry with you.

But I cry because I never wanted to be a hero in this pandemic.

-Unwilling hero

Everyone at work is spewing their COVID anxieties.

I feel drenched in their undigested hurt and their inability to cope with their feelings.

Leave my mind alone. I have enough of my own to work through.

-the Limbic Circuit

There is so much in my head,

But if I keep moving, doing and producing, it feels better.

To sit with it all is painful.

So I keep moving to avoid the pain.

-COVID Productivity

We will make it so YOU can't breathe.

You tried to eradicate us.

Watch us as we eradicate you. 